POETRY AS A FOREIGN LANGUAGE IN HEATHER DOHOLLAU AND ANDRÉ DU BOUCHET

\title{
CLÉMENCE O’CONNOR
}

As a field within French studies, the poetic potential of bilingualism in the postwar period has been slow to gain critical attention. It is almost as if France's literary-critical establishment remained slightly suspicious towards the idea of bilingualism as a poetic resource, despite the long list of bilingual poets in French in the twentieth-century canon. ${ }^{1}$ In consequence, most of my primary sources in this paper come from texts on translation, as little is published on bilingualism as such - Beckett being a major exception. We may however note a rising interest in the theme, with landmarks such as Eric Robertson's pioneering study of Arp, or the publication which brought to a close the ambitious Franco-Romanian project 'Bilinguisme, double culture, littératures' (2009$11)^{2}$

If bilingualism in modern poetry remains understudied, it is not for lack of hints from the poets themselves. In writing poetry, most strive towards a utopia which they call an 'other language': what Mallarmé names 'mot total, neuf, étranger à la langue'3 resonates with Michaux's 'avant-langue', ${ }^{4}$ which is akin to du Bouchet's 'langue étrangère dans la langue', 'autre interne du langage' or 'langue première', 5 Gaspar's 'origines de toute langue et de tout langage' ${ }^{6}$ and Dohollau's 'langue inconnue'. ${ }^{7}$ The notion of 'other language' is fundamental to reflexive discourse and creative practice alike, with many poets publishing translations as well as their own texts. Exploring that 
notion yields valuable insights into the nature of what is attempted in writing poetry, and leads us to challenge several commonplaces, such as the primacy of the mother tongue in a writer's allegiances, or the self-enclosed genre poetry is often perceived to be: an important juncture point with the philosophy of language will come to light, as will potential political implications.

In the pursuit of an 'other language' through poetry, being bilingual can be a decisive advantage. I shall focus on two bilingual poets of the same generation, born in the mid-nineteen twenties. André du Bouchet (1924-2001) is relatively well known, while Heather Dohollau (1925-2013) is less familiar. Although their paths did not cross, they share in common their French-English bilingualism. Du Bouchet's mother was of Jewish-Russian descent. Under Vichy law she was no longer able to work as a doctor and the family went into exile. From the age of seventeen, and for about eight years, du Bouchet studied and taught in Amherst and Harvard, with no social use of French, and it was only on his return to France that he started composing in his first language. Even looking back at his childhood, as the child of an American citizen born in Russia, cared for by German nannies, he recalls 'un sentiment de proximité avec des langues inconnues' ${ }^{8}$ Dohollau was born in the Rhondda Valley, then one of the mining valleys of South Wales, but she went to France as a young woman following her mother's death and lived there from the early fifties. ${ }^{9}$ In 1966 she adopted French as her writing language, in which all fourteen of her books were published. Her sense of linguistic duality may have been heightened by the awareness of living in areas that are themselves bilingual: Wales and Brittany (she had some contact with both Welsh and Breton, even though she spoke neither). As a poet, her consciousness seems informed by a latent translatability or 'voix 
retournée' - a phrase which itself splits into two meanings. ${ }^{10}$ Her voice is turned inside out like a glove as she switches languages, but also potentially returned to some kind of origin, in spite of the successive exiles and losses that mark her work, such as the years of poetic aphasia that followed her mother's death. In that instance, we may read 'retournée' as a deliberate anglicism: her voice was returned, or restored to her, when she settled in France permanently.

In what $\mathrm{du}$ Bouchet and Dohollau wrote on translation and on French as a language, the notion of a fruitful 'difficulty' prevails; it will be my starting point. ${ }^{11}$ I shall then move on to their treatment of poetry as a foreign language, which will yield some valuable insights into the access they seek into what could be called the unsaid - as embodied in the poem's interplay with whiteness, and distinct from an entirely inchoate ineffable.

Both poets associate French with difficulty. Dohollau recollects finding, as a child, a French grammar book belonging to her father and assessing its contents in these words: 'I wonder how French children can learn their language. It's far too difficult for their age.' ${ }^{12}$ The term would later gain new relevance: '[1]a difficulté ne s'est pas estompée depuis 1966 [the date of her shift to French]: elle est presque un absolu, une qualité intrinsèque à mon rapport au français. ${ }^{13}$ In the same interview, she explains: '[1]a difficulté du français crée son entrée. Le problème de sa propre langue, c'est l'absence apparente d'obstacle. Se cogner contre la difficulté est une force et une direction qui peut aussi par la suite se transposer dans la "première langue". ${ }^{14}$ In talking about French as the matter of poetry, the emphasis is on physical, tangible resistance. Her language change appears as promising ('une entrée') but also arduous ('se cogner contre') - and 
indeed she often evokes it as a door or a wall. This experience introduces a heightened self-consciousness in grappling with difficulties that are inherent in the poetic handling of any language. The empowering effect of difficulty ('une force et une direction') lies in its ability to be transposed: the mother tongue not only loses its primacy but is regenerated by the 'daughter tongue', as Dohollau called it. Poetry writing is about finding and sustaining an illuminating distance to words. When awarded the Légion d'Honneur in 2000, she quoted Valéry's aphorism to make this point: 'Une difficulté est une lumière. Une difficulté insurmontable est un soleil. ${ }^{15}$

Du Bouchet's first collection, Dans la chaleur vacante, is pervaded with the word 'mountain', which according to him, embodied his struggle with French at the time of his return from the United States: 'le mot de "montagne" [...] n'était autre que la langue que je commençais à habiter et à laquelle je me heurtais. ${ }^{16} \mathrm{He}$ also calls French 'une langue avec laquelle je me trouve en lutte', ${ }^{17}$ yet this struggle is a fruitful one: 'en plusieurs langues, nous nous retrouvons, ${ }^{18}$ an assertion which would be echoed by the notion of 'voix retournée' in Dohollau. For both poets, it is essential to find ways of cultivating this wrestling with language, and the estranged rapport to words that it institutes. Hence their interest in translation: du Bouchet explains,

Je n'ai pas envisagé ces traductions très différemment de mon propre travail. Je traduis parce que j'entretiens un rapport de difficulté avec ma propre langue: il s'agit d'abord de me traduire moi-même en français, de traduire en français, dans ma propre langue, des impressions, des pensées. ${ }^{19}$ 
The kind of translation he refers to is that originating with the German Romantics and radicalized since Benjamin. Its ethos is one of faithfulness through distance, because what one translates always has to be a relation:

[J]e dois rendre compte de la chose qui m'a échappé, c'est-à-dire de la chose elle-même et de l'écart qui m'en sépare. Je dois rendre compte de ma visée et en même temps de ce qui me sépare de l'objet auquel je m'attache. Donc je traduis un rapport. ${ }^{20}$

To achieve this, according to Benjamin's precept, 'c'est vis-à-vis de sa propre langue que 1'on exerce sa liberté. ${ }^{21}$ Translation is required not only from, but into a foreign language if it is to preserve a sense of the original's otherness. ${ }^{22}$ Dohollau, too, embraces this view of translation in her text on her friend Pierre Jean Jouve's translation of Shakespeare's Sonnets:

A translator must first live with the words he is to translate, feeling their shape and weight, and above all their rhythm, so as to bring his own language as near as possible to them. ${ }^{23}$

The metaphors for this process are distinctly haptic. 'Feeling their shape and weight', the translator moves like a blind man through the text, as he does too in du Bouchet: 'comme à tâtons, traduire... Sur un écart, manifeste alors, confirmé, de deux langues au moins non plus l'une à l'autre, mais l'une comme l'autre, étrangères... ${ }^{24}$

Negotiating the blind spots between languages is evidently an important aspect of translating, but the aim is not to iron them out. Alien rhythms and new meanings are introduced within known words, inviting us to lend them an estranged ear. And this, in the hope that derailing one's writing language will cause an upheaval: 'Lorsque je traduis, je participe au natal, à l'inconnu qui, parce qu'il me surprend, me prive de ma 
maîtrise de la langue'. ${ }^{25}$ A certain loss of control over language allows a zone of wordless significance to manifest itself. The modus operandi of writing and its finality seem to merge into this letting go and heightened attentiveness to what lies between languages. Given du Bouchet's familiarity with the writings of Heidegger, it seems highly probable that the notion of Gelassenheit should act as a subtext to the passage just quoted.

In turn, and moving away from translation, the reader is invited to experience foreignness as what marks the literary quality of a work. Both Dohollau and du Bouchet have invoked Proust to convey this idea, the former in a talk given in the 1990s, the latter in these words:

Vous vous souvenez du propos de Proust sur les livres qui, lorsqu'ils sont vivants, semblent toujours écrits dans une sorte de langue étrangère. Sous chaque mot, chacun de nous met son sens, qui est souvent un contresens. Mais dans un beau livre, tous les contresens sont beaux. Dans cette langue comme étrangère, l'important est de se découvrir aux prises avec elle. ${ }^{26}$

Beauty in literature appears where it lends itself to an exploration which is also an involvement, indeed a struggle ('aux prises avec elle'). ${ }^{27} \mathrm{Du}$ Bouchet attaches positive connotations and even beauty to the 'misreadings' thus created.

But precisely how does poetry compare to the laborious and frustrating experience of getting to grips with an unfamiliar language? Poetry writing (and reading), too, works against the automatic way in which we tend to understand our own language and to treat words as mere commodities for meaning. Spatialized on the page in a way that sets it apart from everyday language, the poem does not allow words to lose their sensorial reality, or set phrases to obscure the meanings of their individual words. It exercises 'cette faculté critique qui ne mord pas sur la matière', ${ }^{28}$ in du Bouchet's words, 
and uses the 'shape, weight and rhythm' of words in the same way as a sculptor might foreground the grain and irregularities of wood. ${ }^{29}$

This tendency finds illustration in Dohollau's poems where, owing to contexts of linguistic estrangement, a 'mistake' makes sense, coincidentally injecting new life into a word or phrase. 'À Emilia Rowles' opens with a description of the statue which stands at the entrance of the Palazzo Ricci-Paracciani on the Via Giulia in Rome. ${ }^{30}$ It represents a woman holding a book, yet she is looking straight ahead of her:

Car vous ne lisez pas

Les amandes de vos yeux

Ont le blanc-seing des rêves

Un jour j'ai compris

The white seeing

Et maintenant devant votre regard

Je me trompe peut-être encore $[\ldots]^{31}$

Dohollau is fascinated by the kernels of a statue's eyes, which are often devoid of irises or pupils. Here, they are metaphorically determined by the term 'blanc-seing', literally designating a legal document left blank for someone else to fill, but signed in advance. Like the phrase 'carte blanche', it connotes freedom and unbounded possibility, all the more so here as it determines dreaming: 'le blanc-seing des rêves'.

This enigmatic metaphorical drifting comes into its own as the next two lines unravel the meaningful mismatch: the speaker once understood 'blanc-seing' as meaning 'the white seeing', misled by the graphic similarity between the French and the English. Or is 'misled' really the right word? The confusion is evoked in terms of comprehension: 'Un jour j'ai compris'. Even though this verb introduces the nature of the mistake ('The white seeing'), the passé composé denotes an epiphany. In the last two lines, what 
grammar hints at is made explicit: the mistake has given a name to the mesmerizing gaze of a statue. This 'white seeing' may be what prompts the speaker to address the artefact as a person, as her respectful vouvoiement indicates. In the face of a specific experience ('Et maintenant devant votre regard'), a strictly nonexistent phrase is recognized as lastingly meaningful: 'Je me trompe peut-être encore'.

The assimilation of the 'correct' meaning of 'blanc-seing' is met with resistance, suggesting that the relationship between a subject and a language is not purely that of the smooth, gradually accumulative acquisition of a system of signs. Rather, the chemistry between new words and a person's psyche and experience can make certain mistakes not only persistent but creatively fruitful, reinventing the naming process and releasing the poetic potential held by words. As this poem shows, some of 'le blanc-seing des rêves' can be retrieved through a cultivated attentiveness to these phenomena. Difficulty can now be construed as the promising, if precarious, space of possibility opened up by a refusal to presuppose that a language can wholly own, or belong to an individual, or that meaning is best constructed within a language rather than on its less controlled borders.

This poetic stance anticipates Derrida's reflection on 'une sorte d'"aliénation" originaire qui institue toute langue en langue de l'autre: l'impossible propriété d'une langue $^{, 32}$ - a point he clarifies in relation to Paul Celan:

[U]ne langue n'appartient pas. Qu'elle ne se laisse pas approprier, cela tient à l'essence de la langue. Elle est, la langue, cela même qui ne se laisse pas posséder, mais qui, pour cette raison même, provoque toutes sortes de mouvements d'appropriation. ${ }^{33}$

Like Derrida, who was Dohollau's friend and correspondent in the last thirteen years of his life, such texts as 'À Emilia Rowles' challenge the post-Romantic tendency to regard 
language, country and collective sense of belonging as conceptually interdependent. ${ }^{34}$ In fact, such texts diametrically reverse the subject's rapport with language in favour of an allegiance to a process of re-invention, operating in a comparable way to 'nonappartenance' in Edmond Jabès or 'dépossession' in Henri Thomas (two other bilingual poets), or to what Serge Champeau has described as 'la perte du langage constitutive de la poésie'. ${ }^{35}$

As we have seen, poetry pursues an defamiliarizing language within French, renewing it from within. This is an enterprise which it shares in common with philosophy: Wittgenstein seeks 'to run against the boundaries of language', ${ }^{36}$ Heidegger strives towards 'what must remain unspoken, what is held back in the unsaid', ${ }^{37}$ Benjamin hints at 'une chose $[\ldots]$ qui ne peut être atteinte par aucune d'entre elles [aucune langue] isolément', ${ }^{38}$ Derrida imagines a different 'structure of reference ${ }^{39}$ which might find shape in a poetic form he calls 'avant-première langue', 'vieille neuve langue' or idiome. ${ }^{40}$ These passages strongly echo the citations from poets quoted at the opening of this essay. Therefore it seems important to ask what specifically poetic resources, such as the visual resource of whiteness, are deployed in Dohollau and du Bouchet to perform that interplay with the limits of language, at the limit between languages.

$\mathrm{Du}$ Bouchet's aesthetic of whiteness is one of acute tension: the first page of 'L'Inhabité' seems to start with an acknowledgement of defeat on the part of words. ${ }^{41}$ They are confined to the bottom and margins of the first page, a few broken shards of lines that are dwarfed by the central whiteness, by the non-verbal, that which words cannot inhabit. Yet this other of words can also be perceived as their origin: 
Nous nous arrêterons,

pour la hauteur, dans le vent qui n'assèche pas les lointains, sur l'empierrement debout.

et s'ouvre encore.

Notre appui souffle. Le ciel est comble,

By emphasizing the verticality of the page, whiteness heralds the words 'hauteur' and 'debout'. The way in which whiteness scatters the lines, pushing them aside, visually suggests the impact of 'le vent' and the verb 'souffle'. The word 'ouverture' echoes the vacancy in the middle of the page. Whiteness thus interacts with words, inviting us to reevaluate our relation to them, their relation to each other, to the title and to the page. Such processes in du Bouchet have already been well studied, including in their dialogue with Giacometti's visual idiom, so more attention will now be paid to Dohollau's less familiar aesthetic. $^{42}$

Dohollau's typical poem is more tightly woven, although she also uses generous margins, allowing it to breathe and reverberate in its space. Within the poem, whiteness embodies a third element alongside French and English, 'dans le mouvement utopique d'une volonté de poème comme en dehors des langues existantes', as Daniel Lançon has put it. ${ }^{43}$ 'En dehors', and yet not quite: rather, this third element is poised halfway between pure virtuality and the emergence of a 'vouloir dire' or 'intentionnalité'. ${ }^{4}$ Rather than suggesting a creative decision, these phrases designate 'a change of light, an opportune moment' when 'un espace préliminaire' is opened up for the linguistically uncharted, that which does not yet fall within the scope of either language: 
à partir d'un no man's land

une ligne de partage - de crête

je descends d'un côté ou de l'autre

dans une langue ou dans l'autre

d'un lieu sans mots - ou sans mots

comme tels ${ }^{45}$

The writing process is described as a descent from the ridge of a pre-verbal unsaid down to the words of either language. When translating her own poems, Dohollau also evokes 'un tiers' to which she can refer: ${ }^{46}$ the translating process is a double crossing, at once from French into English and from the third element into English. In the poem quoted above, the alien quality of the unsaid is brought forward by the shift to the English 'no man's land', a phrase used in French but retaining a foreign ring. Yet the pre-verbal is also their origin, 'un lieu' or, as Dohollau has also called it, a 'shape', a 'music' which will inform the poem-to-be. ${ }^{47}$ The final qualification 'ou sans mots/comme tels' confirms that the unsaid is not purely virtual, but has a form of spectral reality even in its dormant state. Dohollau determines both the unsaid and whiteness as an unplaceable origin with reference to her bilingualism and in dialogue with Derrida's Khôra, a text to which Dohollau felt particularly close. Laying themselves open to this wordless matrix, Dohollau's collections increasingly deploy visual resources to accommodate '[1]'autre poésie’:

L'autre poésie celle qui n'est pas écrite mais que l'écriture projette. L'herbe transparente d'un semis d'encre ${ }^{48}$

The brevity of this fragment and the typographic interstice that stretches it open seem to leave unappropriated space for the unsaid to well up, 'pour garder l'impossible intact' as 
she writes in an earlier fragment quoted by Derrida in a letter to Dohollau. ${ }^{49}$ Since 2003 , she has replaced punctuation with such white gaps (or 'blancs', as she called them to emphasize their colour value). Their widespread use has come to shape a visual form of rhythm which, without undoing the poem's fabric, nonetheless suggests small cracks or folds in the textual space.

A different illustration of Dohollau's use of the blanc is found in the following stanza, written in memory of Derrida, after Dohollau's first visit to Cerisy after his death. It reads as a tentative search for traces of his presence there. But in the face of death, words falter; the non-verbal language of the real seem most eloquent:

cerné de silence tout tremble de traces les mots du murmures des feuilles sibylles et l'oiseau qui de branche en branche suspend la suite

This sense of suspension, of an uncertain, secret, unintelligible language spoken by the place, is partly rendered by the dense alliterations, but partly also by the use of the white space in the fifth line. It makes the poem's outline indefinite, as if the traces of words were themselves trembling, visually marked by the textual instability and open-endedness Derrida writes about as 'l'indécision':

Celle-ci semble interrompre ou suspendre le déchiffrement de la lecture mais en vérité elle en assure l'avenir. L'indécision tient à jamais l'attention en haleine, [...] suspendue au souffle de l'autre parole et de la parole de l'autre - là même où elle pourrait sembler encore inintelligible, inaudible, intraduisible. 50 
Dohollau's blanc invites into the text the liminal space of 'l'indécision', receptive to otherness in its 'inintelligible' dimension and its resistance to translating.

To give a third example, the use of blancs is generalized in this poem about a derelict white façade in Naples, painted by by eighteenth-century Welsh artist Thomas Jones:

Thomas Jones

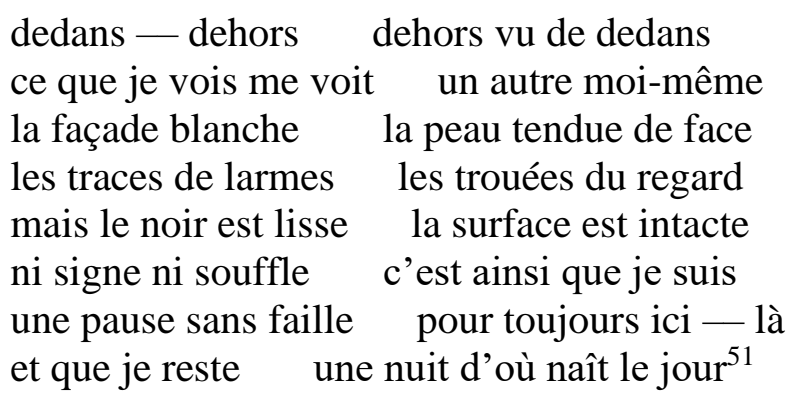

Here, blancs are used to create an irregular crack running across the poem. In the painting, the façade is also pierced, not only with mysteriously opaque windows, but with cracks and asperities that draw attention to its 'surface'. Yet no matter how long the eye lingers on its uneven texture, the wall will keep its secret, as such 'intacte', 'sans faille' and impenetrable as the canvas itself. The poem's own white fissure running through the black printed words, and the use of two long hyphens, translate a desire to move into the façade, and into the surface of the painting - a central element to Dohollau's writings on visual artefacts. ${ }^{52}$ As the blancs tear open 'trouées' within the text, they also create silences ('une pause') in its musicality, reflecting in their rhythms the secrecy and solitude observed in Jones's painting, but also the open-endedness of Derrida's 'indécision': 'je reste une nuit d'où naît le jour'. As Clive Scott stresses, such pauses 
constitute a major genre-specific resource of verse, 'embedded in its substance, full of speechless expressivity, of acoustic and semantic reverberation'. ${ }^{53}$

Thus it is through visual poetic resources that Dohollau attempts to preserve the sensorial language of visuality as such within the space of the poem. To use her own metaphor, it is as if the text were lined with a visible hem, as if we could turn it inside out to reveal the unsaid on its other side, in a visual enactment of 'la voix retournée'. Significantly, here, the two languages that engage in a dialogue and translation are not directly English and French, but words and pictoriality. Perhaps it is no wonder if Dohollau and du Bouchet, two bilingual poets, are also those whose engagement with the visual arts has been among the most significant in the contemporary period. Their quest for blind spots to be translated in poetry extends beyond the inter-linguistic, to the intermedial. And translating visuality in its very alienness to words has inscribed it deeply into their poetics, though the impact on the poem differs in the two authors.

Words, therefore, need to undertake a constant translation of the unsaid, being able neither to articulate it nor remain silent before it. Yet for Dohollau, this aporia is eased by the virtual co-presence of two languages in the creative process: 'Du fait que les deux possibilités existent en moi, elles libèrent l'intentionnalité du poème, même si je ne manie pas les deux langues simultanément. ${ }^{54}$ If no single language may give voice to the unsaid, the space between languages may help us form a sense of it. In an epigraph to an unpublished sequence of bilingual poems on Wales, she quotes du Bouchet:

De cette langue à l'autre

Quelquefois sera touché au passage ce qui va hors de l'une et de l'autre 55 
The liminal stance adopted by both poets allows them passing glimpses of the unsaid in their crossings from one language to the other, from one blind spot to another. The bilingual poet's task, like the translator's, is to point to 'une langue inconnue' as if outside existing languages. Even as they lay bare the relativity of different linguistic maps, bilingual poets tentatively reach out for what no single language can translate. To use Dohollau's recurrent metaphor of whiteness for the unsaid, the latter is the colourneutral value from which all colours are decomposed before they combine into infinitely varied shades. Different languages brought into contact briefly reveal the unsaid, just as the simultaneous perception of colours on a fast-spinning circular spectrum makes us see whiteness, 'Mêlant toutes les couleurs/À l'envers d'une blancheur'. ${ }^{56}$

\footnotetext{
${ }^{1}$ Non-French poets in French in the postwar period include Lorand Gaspar (Hungarian), Salah Stétié, Andrée Chedid and Vénus Khoury-Ghata (Lebanese), Jabès (Egyptian, Jewish), Emil Cioran (Romanian), Jaccottet and Gustave Roud (Swiss). Poets who are also translators (du Bouchet, Bonnefoy, Henri Thomas, Jaccottet, Lorand Gaspar or Jouve, to name only a few) also position themselves between several languages, as do bilingual writers like Beckett, who composed and translated poems in English and French. Examples of handlings of bilingualism in postwar French poetry include the notion of 'non-appartenance' in the work of Jabès (see Steven Jaron, Edmond Jabès: The Hazard of Exile (Oxford: Legenda, 2003), pp. 156-67). On Guillevic's conflicted attitude to French in relation to both his Breton and Alsatian backgrounds, see Maria Lopo, Guillevic et sa Bretagne (Rennes: Presses universitaires de Rennes, 2004), pp. 31-6. On the influences of French and Flemish on Michaux, see Margaret Rigaud-Drayton, Henri
} 
Michaux: Poetry, Painting, and the Universal Sign (Oxford: Oxford University Press, 2005), pp. 10-33. Lorand Gaspar's poetics of nomadism is explored in Daniel Lançon, ‘La Naissance de l'auteur français', Europe, no. 918 (October 2005), 69-83.

${ }^{2}$ Eric Robertson, Arp: Painter, Poet, Sculptor (New Haven and London: Yale University Press, 2006). Béatrice Bonhomme, Maria Cristina Pîrvu and Dumitra Baron (eds.), Traversées poétiques des littératures et des langues (Paris: L'Harmattan, 2013). This volume is not confined to poetry, as the title might suggest.

${ }^{3}$ Stéphane Mallarmé, Euvres complètes, ed. by Bertrand Marchal, 2 vols (Paris: Gallimard, 2003), II, p. 213.

${ }^{4}$ Quoted in Serge Champeau, Ontologie et poésie: trois études sur les limites du langage (Paris: Vrin, 1995), p. 26 and p. 266.

5 'Hölderlin aujourd'hui', in André du Bouchet, L'Incohérence (Paris: Hachette, 1979), n.p. '[L]a langue étrangère dans la langue' also appears in 'Notes sur la traduction', in Ici en deux (Paris: Mercure de France, 1997), n.p. and in Pourquoi si calmes (Montpellier: Fata Morgana, 1996), p. 18.

6 'Approche de la parole', in Lorand Gaspar, Sol absolu, Corps corrosifs et autres textes, avec un essai d'autobiographie (Paris: Gallimard, 1982), p. 29.

${ }^{7}$ Heather Dohollau, Le Point de rosée (Bédée: Folle Avoine, 1999), p. 79.

${ }^{8}$ André du Bouchet, “'À la croisée des langages”, entretien avec Monique Pétillon, 10 juin 1983', L'Etrangère, special issue on André du Bouchet, 2 vols, I, nos. 14 and 15 (May 2007), 279-84 (p. 281). See also Jean-Baptiste de Seyne, 'L’Atelier', ibid., II, nos. 16, 17 and 18 (May 2007), pp. 49-53. 
${ }^{9}$ Unless stated otherwise, biographical information on Dohollau given in this essay is taken from Clémence O’Connor and Heather Dohollau, 'Biographie', in Heather Dohollau: l'évidence lumineuse: colloque de Cerisy 9-12 juin 2005, ed. by Daniel Lançon and Tanguy Dohollau (Bédée: Folle Avoine, 2006), pp. 161-164. 10 Heather Dohollau, “Londres”, Matière de lumière (Bédée: Folle Avoine, 1985), n.p. ${ }^{11}$ Dohollau translated some of Salah Stétié's poems into English, as well as many of her own, while du Bouchet translated Hölderlin, Paul Celan, Shakespeare and Faulkner into French.

12 Private interview, 19 December 2006.

${ }^{13}$ Private interview, October 2006.

14 Quoted in Clémence O’Connor and Suzanne Allaire, 'Entretien avec Heather Dohollau', Friches, no. 110 (May 2012), 19-23 (p. 19).

${ }^{15}$ Also quoted by Dohollau in ibid., p. 19. The quotation is from Paul Valéry, Euvres, ed. by Jean Hytier, 2 vols (Paris: Gallimard, 1957-1960), II, p. 795, from Mauvaises pensées et autres.

${ }^{16}$ Quoted in Monique Pétillon, ‘À la croisée des langages’, p. 281.

${ }^{17}$ Quoted in Elke de Rijcke, 'Entretien avec André du Bouchet', L'Etrangère, II, pp. 277-98, pp. 277-278.

${ }^{18}$ L'Incohérence, n. p.

${ }^{19}$ Quoted in De Rijcke, 'Entretien', p. 277.

${ }^{20}$ Ibid., p. 279.

${ }^{21}$ Walter Benjamin, 'La Tâche du traducteur', in Euvres, transl. by Maurice de Gandillac, Rainer Rochlitz and Pierre Rusch, 3 vols (Paris: Gallimard, 2000), I, p. 259. 
${ }^{22}$ See Emma Wagstaff's investigation of 'the foreign language', and particularly of translation as 'a model for the writing of poetry', in du Bouchet and Jaccottet in Provisionality and the Poem: Transition in the Work of du Bouchet, Jaccottet and Noël (Amsterdam: Rodopi, 2006), pp. 165-87. See also Victor Martinez, André du Bouchet: poésie, langue, évènement (Amsterdam: Rodopi, 2013), pp. 50-5.

${ }^{23}$ Manuscript 'A Passionate Place', undated text on Jouve's translation of Shakespeare's sonnets, Dohollau's collection, p. 2.

24 'Hölderlin aujourd'hui', in L'Incohérence, n.p. ${ }^{25}$ Quoted in De Rijcke, ‘Entretien’, p. 279.

${ }^{26}$ Du Bouchet, quoted in Pétillon, 'À la croisée des langages', p. 283. The quotation is from Marcel Proust, Contre Sainte-Beuve (Paris: Gallimard, 1954), pp. 297-8. This passage was also quoted by Dohollau in a manuscript 'Lumière de lecture - lecture de lumière', rough script for a talk given at an event held by the theatre company Folle Pensée in Saint-Brieuc, dated 1992-3, Dohollau's collection, p. 3.

${ }^{27}$ De Rijcke, ‘Entretien’, p. 281.

${ }^{28}$ André du Bouchet, Une lampe dans la lumière aride (Saint-Just-la-Pendue: Le Bruit du temps, 2011), p. 254.

${ }^{29}$ Dohollau, ‘A Passionate Place’, p. 2.

${ }^{30}$ A photograph of the statue (Ignoto, La Moglie del marchese Campana, dated 1830) is available in Luigi Salerno et al. (eds.), Via Giulia, una utopia urbanistica del 500, $2^{\text {nd }}$ edn (Rome: Stabilimento Aristide Staderini Spa, 1975), p. 391.

${ }^{31}$ Matière de lumière, n.p. 
32 Jacques Derrida, Le Monolinguisme de l'autre ou la prothèse d'origine (Paris: Galilée, 1996), p. 121.

33 Jacques Derrida, 'La Langue n'appartient pas - entretien avec Évelyne Grossman', Europe, special issue on Paul Celan, 861-2 (2001), 81-91 (p. 85).

34 This intellectual construction dates back from the rise and linguistic unification of nation-states. It was not until the late eighteenth century that the early Romantics grounded national identity on vernacular language. See Benedict Anderson, Imagined Communities: Reflections on the Origin and Spread of Nationalism, $2^{\text {nd }}$ edn (London: Verso, 1991) and, for an example from twentieth-century Wales, R. S. Thomas, Cymru or Wales? (Llandysul: Gomer, 1992).

${ }^{35}$ See Hervé Ferrage, 'Henri Thomas, la dépossession et la grâce', Nouvelle revue française, 501 (1994), 55-68, and 'Le Langage comme patrie', in Henri Thomas, ed. by Paul Martin (Cognac: Le Temps qu'il fait, 1998), pp. 15-25. On Jabès and 'nonappartenance', see Jaron, Edmond Jabès: The Hazard of Exile.

${ }^{36}$ Ludwig Wittgenstein, 'A Lecture on Ethics', The Philosophical Review, 74 (1965), 312 (pp. 11-12).

${ }^{37}$ Martin Heidegger, Unterwegs zur Sprache (Pfullingen: Neske, 1959), p. 253; translated by David White in Heidegger and the Language of Poetry (Lincoln: University of Nebraska Press, 1978), p. 70.

${ }^{38}$ Benjamin, 'La Tâche du traducteur', p. 250.

${ }^{39}$ Interview printed in Richard Kearney, Dialogues with Contemporary Critical Thinkers: The Phenomenological Heritage (Manchester: Manchester University Press, 1984), pp. 123-4. 
${ }^{40}$ Derrida, Le Monolinguisme de l'autre, p. 118; 'Desceller ("la vieille neuve langue")', in Points de suspension: entretiens (Paris: Galilée, 1992), pp. 123-40, particularly pp. 127-8. Derrida also uses a foreign language in the title of his text 'Che cos'è la poesia?', ibid., pp. 303-8.

${ }^{41}$ In L'Inhabité, with engravings by Alberto Giacometti (Paris: Hugues, 1967), p. 7.

${ }^{42}$ See Martinez, André du Bouchet, pp. 63-77, and Wagstaff, Writing Art: French

Literary Responses to the Work of Alberto Giacometti (Oxford: Peter Lang, 2011).

${ }^{43}$ Daniel Lançon, “'La Joie du don”', in Heather Dohollau: l'évidence lumineuse, pp. 910 (p. 9). The phrase 'volonté de poème' is taken from Dohollau, L'Adret du jour (Bédée: Folle Avoine, 1989), n.p.

${ }^{44}$ Private interview, 11 July 2007.

${ }^{45}$ Private interview, 11 July 2007; Une suite de matins (Bédée: Folle Avoine, 2005), p. 47.

${ }^{46}$ Private interview, 6 October 2006.

${ }^{47}$ Private interview, 29 February 2002.

${ }^{48}$ Un regard d'ambre (Bédée: Folle Avoine, 2008), p. 101.

${ }^{49}$ Heather Dohollau, La Venelle des portes (Bédée: Folle Avoine, 1996), p. 76.

Inscription in Dohollau's special edition of Derrida with his Replies: Contemporary Philosophers - Philosophes contemporains, Revue Internationale de Philosophie, 52-53 (1998). Michael Bishop perceptively sees this fragment as Dohollau's 'motto': see Contemporary French Women Poets, 2 vols (Amsterdam: Rodopi, 1995), I, p. 41.

${ }^{50}$ Jacques Derrida, Béliers: le dialogue ininterrompu: entre deux infinis, le poème (Paris: Galilée, 2003), pp. 37-8. 
${ }^{51}$ Heather Dohollau, Le Dit des couleurs (Bédée: Folle Avoine, 2003), p. 72. The painting is Buildings in Naples (1782), oil on paper. A digital reproduction can be retrieved from WikiArt at https://www.wikiart.org/en/thomas-jones/buildings-in-naples1782. Accessed on16.03.2017.

${ }^{52}$ See O’Connor, 'Translating Non-Figuration: Heather Dohollau's Poems on 'Pure Visuality', French Studies, special issue ‘New Ekphrastic Poetics', ed. Susan Harrow (July 2010), 276-289 (pp. 284-287).

${ }^{53}$ Clive Scott, Reading the Rhythm: The Poetics of French Free Verse 1910-1930 (Oxford: Oxford University Press, 1993), p. 20.

${ }^{54}$ Quoted in O’Connor and Allaire, 'Entretien avec Heather Dohollau', p. 20.

${ }^{55}$ Translated into English by Dohollau in the 2003 manuscript 'Poèmes: Aberystwyth Saint Brieuc 1973-2003', Dohollau's collection. The poems on Wales in this fascicle are reprinted in Une suite de matins (2005), pp. 9-22. The lines quoted are from du Bouchet, Annotations sur l'espace non datées (carnet 3) (Fontfroide-le-Haut: Fata Morgana, 2000), p. 8.

${ }^{56}$ La Venelle des portes (Bédée: Folle Avoine, 1996), p. 9. 